\title{
THE ROLE OF HUMAN RESOURCES MANAGEMENT IN OPTIMIZING WORK PROCESSES
}

\author{
Cătălina SITNIKOV ${ }^{a *}$, Ionela STANECI (DRINCEANU) ${ }^{b}$, Costinel Cristian MILITARU ${ }^{c}$, \\ Mariana Paraschiva OLARU (STAICU) ${ }^{d}$, Ionuț RIZA ${ }^{e}$ \\ ${ }^{a},{ }^{b},{ }^{c},{ }^{d},{ }^{e}$ University of Craiova, Romania
}

DOI: $10.24818 / \mathrm{IMC} / 2020 / 04.01$

\begin{abstract}
It is known that, for a long time, the organizations focused on obtaining the profit after marketing their own products that responded to a solvable demand. As a result, the problems of human relations within the organizations were considered complementary, they were entrusted to a chief of staff, who had in this respect a series of administrative, legal and disciplinary responsibilities, specific to the employees. However, gradually, the fields of activity and the type of concerns of the personnel compartments expanded, becoming more and more the social purpose of the organization, which also caused the change of the place and the role of the employees within it. The importance of the personnel function increased, causing changes even in the structure of the respective compartments: the service or the personnel office became a direction of social relations or a direction of human resources, directly subordinated to the general manager of the company. In this sense we can affirm that of all the functions of the company, the personnel function is probably the one that has experienced the most spectacular and most important evolution during these last ten years. This evolution will continue in the future, both in terms of the content of the function and the profile of the people who exercise it. In this paper we set out to systematically analyze the main processes integrated in the management of human resources practiced by modern organizations.
\end{abstract}

KEYWORDS: employees, employee performance, human resources, management, organization.

JEL CLASSIFICATION: 015

\section{INTRODUCTION}

Human resource management is conventionally defined as a set of activities that ensure the procurement, development and preservation of the human resources an organization needs, in order to achieve its objectives. Such a conception regarding the management of human resources emphasizes, first of all, the description of the component activities, without trying to explain the specific objectives pursued by carrying out these activities (Kearns, 2012). Therefore, it requires a reformulation of human resource management, widespread today, which will open in this area, the way of a global, coherent integration allowing phenomena. In general, the system is defined as an entity composed of differentiated and interdependent parts, each of them making a specific contribution to its creation and maintenance. To highlight the dynamic and evolutionary character of a complex social reality, we can define the system as a set of differentiated and interdependent elements that complete and renew a cycle of activities and that use the same resources in order to produce the desired results. The amplification of the concerns in the field of human resources management was also determined by the emergence of the socio-economy, according to which the

\footnotetext{
* Corresponding author. E-mail address: inasitnikov@yahoo.com
} 
technical changes in an organization are based on the prior study of the implications on human resources (impact on the workforce, working conditions, qualification, motivation) and on an action plan in the field of human resources to accompany the application of new technical solutions (Maxwell, 2003). Another economic aspect that can be identified at the level of organizations in developed countries is the fact that wages are not collectively indexed and do not automatically increase in relation to prices. The companies seek to individualize their salaries and their evolution according to the employees' performances, implementing co-interest systems in relation to the results obtained. Negotiations at the enterprise level are of particular importance, as they become in reality the main place for the elaboration and application of social policy.

The objective of this survey is to analyze in a major way the main components of the human resources management system practiced by modern organizations.

\section{SPECIALTY LITERATURE}

Management is the process of setting goals and coordinating staff efforts to achieve them efficiently and effectively. Human resources management is a strategic and coherent approach to the way the most important resources of the organization are managed - the people (Jansen, 2007). Human resources management can be defined as the process of achieving organizational goals by attracting, retaining, developing, removing and using human resources in an organization (Coy, 2002). In the first half of the twentieth century, the transition, in the western countries, from a shortage economy, to a mass consumption economy, gave priority to the quantitative requirements of the production, while the qualitative considerations were passed, in the secondary plane. The economic transformations recorded after the fifth decade of the twentieth century have led to a reconsideration of the qualitative requirements of the production. The re-launch of the economic growth had as main result the increase of the competition. Under these conditions, for many goods, especially for long-term use, buyers have become increasingly sensitive to the value for money for the products they buy. At the company level, the need for a triple effort for innovation, productivity and quality was identified. Under these conditions, human resources management has begun to become a basic factor of economic results, and social strategy, one of the main components of the overall strategy of the organization (Wood, 2009).

On the other hand, the environment, based on increasing international competition, made it impossible to maintain the old methods and techniques of rigid personnel management. In the face of economic uncertainties and fluctuations, organizations were forced to adapt through the flexibility of the workforce: professional mobility, adaptability of qualifications, changes in staff numbers and work schedules according to the market outlets (Jigau, 2007). The evolution of production methods and techniques has led to important changes in personnel management methods. The development of the mechanization of production at the beginning of the 20th century and of the work in the band, respectively of the production in flux, had as main effect the increase of the dimensions of the production units (sections, workshops), thus requiring rigorous administrative methods of management of the employees' staff (their classification, salary, labor discipline). In parallel, the need to rationalize work was felt in order to increase labor productivity (Van Ruysseveldt, 2003). Although it has caused major changes in the content of the staff function, the stage of scientific work organization has given people a reduced importance. During this period, the personnel service had exclusively legal and administrative attributions, regarding the employment, payment of salaries, dismissal, observance of the discipline at work and elaboration of the regulation of internal order. Subsequently, the technical changes allowed and required further enrichment of the content of the staff function (Armstrong, 2003). Thus, the application of the new production techniques required a higher skilled workforce compared to the scientific work organization, according to which the employees had to have an average level of qualification in relation to the assigned activities. At the same time, the rapid pace of the technical changes had a number of effects and at the level of the 
employees, who, besides a higher qualification, had to have the ability to adapt to numerous trades, but especially to broaden their areas of competence (Deaconu et al., 2004). The influence of new technologies (office space in administrative departments, robotics in industrial production) has also led to a polarization of qualifications. On the one hand, high-tech qualifications appeared, which required great efforts from organizations for training and retraining their personnel, and, on the other hand, low-level qualifications, required by the existence of activities of less complexity, with a repetitive character. As a result, the evolution of qualifications created new problems that the personnel compartments had to face, thus enriching the content of the personnel function and pushing its evolution towards the management of human resources (Gavrilă \& Lefter, 2004). The third industrial revolution (IT, electronics, telecommunications, biotechnologies) caused rapid technical changes with direct effects on the increase of labor productivity. In the conditions of diminishing the activity of some companies (the decrease or stagnation of the production) as a result of the market saturation (or the economic recession in a country) the problem of some surpluses of personnel in relation to the normal requirements of the activity appeared. In order to manage this situation, a good knowledge of the evolutions registered in the labor market, the relation between the increase of unemployment and the natural mobility of the labor force, of the imbalances between the supply and the demand of work was needed (Hardingham et al., 2007).

The influence of the technical factors on the evolution of the personnel function can also be highlighted through the high investments that must be made at the level of a job. They require the most efficient use of resources for the recovery of the expenses incurred, thus defending the need to abandon the traditional ways of working, according to a fixed schedule and reorienting to find new work organization solutions: working in three shifts; variable work schedule during the day or week; setting up specialized teams for certain activities at the end of the week (Chivu, 2003).

\section{RESEARCH AND METHOD}

The main purpose of the research was to identify the importance of the components of the human resources management system. In the research carried out, 312 managers from different organizations (energy, IT, industry, health, trade and hotelier industry) were involved. The research study was based on the questionnaire and the size of the sample in this study was a simple random sample. In the process of data analysis, the human resources management was approached as being composed of the following processes:

1. Human Resource planning - evaluating current staff, forecasting future staffing needs, making plans to hire or reduce staff;

2. Recruitment - the search for qualified people to fill different positions, both inside the company and abroad;

3. Selection - testing and interviewing candidates for the best available candidate;

4. Orientation - helping new employees to get used to the work environment, with new colleagues, learning the rules and regulations as well as the benefits offered by the company

5. Training and development - developing programs to help employees improve their skills and learn the activities they will need to perform;

6. Performance evaluation - establishing the criteria for the evaluation of the work, the real accomplishment of the evaluation, the discussion of the results with the employees and the determination of the way to reward and motivate them to obtain high performances;

7. Rewarding - determining the value of salary and other benefits;

8. Tracking the careers of employees - collecting and processing information regarding the promotion, transfer, departure or dismissal of employees.

The data collection was conducted between November 2018 and January 2019, with the help of the questionnaire, a quantitative structured research tool. In the processing phase, processing and analyzing the collected data, the special statistical research software S.P.S.S. (Statistical Package for 
the Social Sciences), using which average, statistical tests were calculated. Following are the results obtained after conducting the exploratory qualitative stage, respectively analyzing the data collected with the help of the questionnaire. With the help of the coding system in the S.P.S.S. statistics program, conventional values were assigned for each process that makes up the human resources management system: missing -0 , very small -1 , small -2 , medium -3 , high -4 , very high -5 (table no. 1).

Table 1. The answers regarding the human resources management system

\begin{tabular}{|c|c|c|c|c|c|c|c|}
\hline PROCES & & ENERGY & IT & INDUSTRY & HEALTH & TRADE & HOTELIER \\
\hline & Missing & 0 & 0 & 0 & 0 & 0 & 0 \\
\hline & $\begin{array}{l}\text { Very } \\
\text { small }\end{array}$ & 0 & 0 & 0 & 0 & 0 & 0 \\
\hline 1. Human & Small & 0 & 0 & 0 & 0 & 0 & 0 \\
\hline Resource & Medium & 0 & 0 & 3 & 3 & 3 & 6 \\
\hline & High & 6 & 3 & 15 & 15 & 33 & 6 \\
\hline & $\begin{array}{l}\text { Very } \\
\text { hight }\end{array}$ & 18 & 18 & 3 & 24 & 39 & 57 \\
\hline & Missing & 0 & 0 & 0 & 0 & 0 & 0 \\
\hline & $\begin{array}{l}\text { Very } \\
\text { small }\end{array}$ & 0 & 0 & 0 & 0 & 0 & 0 \\
\hline 2) Donunitmont & Small & 0 & 0 & 0 & 0 & 0 & 0 \\
\hline 2. Recruitment & Medium & 0 & 0 & 9 & 3 & 3 & 6 \\
\hline & High & 6 & 3 & 9 & 15 & 33 & 12 \\
\hline & $\begin{array}{l}\text { Very } \\
\text { hight }\end{array}$ & 18 & 18 & 3 & 24 & 39 & 51 \\
\hline & Missing & 0 & 0 & 0 & 0 & 0 & 0 \\
\hline & $\begin{array}{l}\text { Very } \\
\text { small }\end{array}$ & 0 & 0 & 0 & 0 & 0 & 0 \\
\hline & Small & 0 & 0 & 0 & 0 & 0 & 0 \\
\hline 3. Selection & Medium & 0 & 0 & 3 & 3 & 0 & 6 \\
\hline & High & 3 & 3 & 12 & 15 & 36 & 21 \\
\hline & $\begin{array}{c}\text { Very } \\
\text { hight }\end{array}$ & 21 & 18 & 6 & 24 & 39 & 42 \\
\hline & Missing & 0 & 0 & 0 & 0 & 0 & 0 \\
\hline & $\begin{array}{l}\text { Very } \\
\text { small }\end{array}$ & 0 & 0 & 0 & 0 & 0 & 0 \\
\hline & Small & 0 & 0 & 0 & 0 & 0 & 0 \\
\hline & Medium & 0 & 0 & 6 & 3 & 0 & 9 \\
\hline 4. Orientation & High & 3 & 3 & 9 & 15 & 36 & 18 \\
\hline & $\begin{array}{l}\text { Very } \\
\text { hight }\end{array}$ & 21 & 18 & 6 & 24 & 39 & 42 \\
\hline
\end{tabular}




\begin{tabular}{|c|c|c|c|c|c|c|c|}
\hline PROCESS & & ENERGY & IT & INDUSTRY & HEALTH & TRADE & HOTELIER \\
\hline & Missing & 0 & 0 & 0 & 0 & 0 & 0 \\
\hline & $\begin{array}{l}\text { Very } \\
\text { small }\end{array}$ & 0 & 0 & 3 & 0 & 3 & 0 \\
\hline 5. Training and & Small & 0 & 0 & 0 & 6 & 9 & 0 \\
\hline development & Medium & 9 & 6 & 9 & 9 & 18 & 18 \\
\hline & High & 15 & 3 & 6 & 15 & 27 & 33 \\
\hline & $\begin{array}{l}\text { Very } \\
\text { hight }\end{array}$ & 0 & 12 & 3 & 12 & 18 & 18 \\
\hline & Missing & 0 & 0 & 0 & 0 & 0 & 0 \\
\hline & $\begin{array}{l}\text { Very } \\
\text { small }\end{array}$ & 0 & 0 & 3 & 0 & 3 & 0 \\
\hline 6. Performance & Small & 0 & 0 & 0 & 6 & 9 & 0 \\
\hline evaluation & Medium & 9 & 6 & 12 & 9 & 21 & 18 \\
\hline & High & 15 & 3 & 3 & 18 & 24 & 39 \\
\hline & $\begin{array}{c}\text { Very } \\
\text { hight }\end{array}$ & 0 & 12 & 3 & 9 & 18 & 12 \\
\hline & Missing & 0 & 0 & 0 & 0 & 0 & 0 \\
\hline & $\begin{array}{c}\text { Very } \\
\text { small }\end{array}$ & 0 & 0 & 3 & 0 & 3 & 0 \\
\hline & Small & 0 & 0 & 3 & 6 & 9 & 3 \\
\hline 7. Rewarding & Medium & 9 & 9 & 9 & 9 & 24 & 21 \\
\hline & High & 15 & 3 & 3 & 18 & 27 & 33 \\
\hline & $\begin{array}{l}\text { Very } \\
\text { hight }\end{array}$ & 0 & 9 & 3 & 9 & 12 & 12 \\
\hline & Missing & 0 & 0 & 0 & 0 & 0 & 0 \\
\hline & $\begin{array}{c}\text { Very } \\
\text { small }\end{array}$ & 0 & 0 & 0 & 0 & 0 & 0 \\
\hline 8. Tracking the & Small & 0 & 0 & 3 & 0 & 0 & 12 \\
\hline careers of & Medium & 6 & 0 & 6 & 6 & 30 & 18 \\
\hline & High & 3 & 0 & 9 & 21 & 33 & 30 \\
\hline & $\begin{array}{l}\text { Very } \\
\text { hight }\end{array}$ & 15 & 21 & 3 & 15 & 12 & 9 \\
\hline
\end{tabular}

Source: developed by the authors based on the collected data

From the analysis of table no. 2, it turns out that the average number of responses regarding the Human Resource planning process is 4.56 , which means that the process is implemented in a very hight proportion. Following the analysis of table 1 we can see that the process is implemented in a very hight proportion in the field: energy, IT, health, trade, hotel industry and a medium level for industry. 
Table 2. Descriptive Statistics - Human Resource planning

\begin{tabular}{|l|c|c|c|c|}
\hline \multirow{2}{*}{} & $\mathbf{N}$ & \multicolumn{2}{|c|}{ Mean } & Std. Deviation \\
\cline { 2 - 5 } & Statistic & Statistic & Std. Error & Statistic \\
\hline Human Resource planning & 312 & 4.56 & .036 & .634 \\
\hline Valid N (listwise) & 312 & & & \\
\hline
\end{tabular}

Source: Processing data obtained through SPSS program

Analyzing table no. 3, it turns out that the average number of responses regarding the Recruitment process is 4.51 , which means that the process is implemented in a very hight proportion. Following the analysis of table 1 , we can see that the process is implemented in a very hight proportion in the field: energy, IT, health, trade, hotel industry and a medium level for industry.

Table 3. Descriptive Statistics - Recruitment

\begin{tabular}{|l|c|c|c|c|}
\hline \multirow{2}{*}{} & $\mathbf{N}$ & \multicolumn{2}{|c|}{ Mean } & Std. Deviation \\
\cline { 2 - 5 } & Statistic & Statistic & Std. Error & Statistic \\
\hline Recruitment & 312 & 4.51 & .039 & .680 \\
\hline Valid N (listwise) & 312 & & & \\
\hline
\end{tabular}

Source: Processing data obtained through SPSS program

From the analysis of table no. 4, it is apparent that the average mean value of the Selection is 4.56, which means that the process is implemented in a very hight rate. Following the analysis of table 1, we can see that the process is implemented in a very hight proportion in the field: energy, IT, health, trade, hotel industry and a medium level for industry.

Table 4. Descriptive Statistics - Selection

\begin{tabular}{|l|c|c|c|c|}
\hline \multirow{2}{*}{} & $\mathbf{N}$ & \multicolumn{2}{|c|}{ Mean } & Std. Deviation \\
\cline { 2 - 5 } & Statistic & Statistic & Std. Error & Statistic \\
\hline Selection & 312 & 4.56 & .033 & .586 \\
\hline Valid N (listwise) & 312 & & & \\
\hline
\end{tabular}

Source: Processing data obtained through SPSS program

Analyzing table no. 5, it turns out that the average response time for the Orientation process is 4.51 , which means that the process is implemented in a very hight proportion. Following the analysis of table 1 we can see that the process is implemented in a very hight proportion in the field: energy, IT, health, trade, hotel industry and a medium level for industry.

Table 5. Descriptive Statistics - Orientation

\begin{tabular}{|l|c|c|c|c|}
\hline \multirow{2}{*}{} & $\mathbf{N}$ & \multicolumn{2}{|c|}{ Mean } & Std. Deviation \\
\cline { 2 - 5 } & Statistic & Statistic & Std. Error & Statistic \\
\hline Orientation & 312 & 4.51 & .036 & .636 \\
\hline Valid N (listwise) & 312 & & & \\
\hline
\end{tabular}

Source: Processing data obtained through SPSS program 
From the analysis of table no. 6, it turns out that the average of the responses regarding the Training and development process has a value of 3.77, which means that the process is implemented in a medium to hight ratio. Following the analysis of Table 1 we can see that the process is implemented in a very hight proportion in the field: IT, hight in: energy, health, trade, hotel industry and a medium level for industry.

Table 6. Descriptive Statistics - Training and development

\begin{tabular}{|l|c|c|c|c|}
\hline \multirow{2}{*}{} & $\mathbf{N}$ & \multicolumn{2}{|c|}{ Mean } & Std. Deviation \\
\cline { 2 - 5 } & Statistic & Statistic & Std. Error & Statistic \\
\hline $\begin{array}{l}\text { Training and } \\
\text { development }\end{array}$ & 312 & 3.77 & .053 & .944 \\
\hline Valid N (listwise) & 312 & & & \\
\hline
\end{tabular}

Analyzing table no. 7, it turns out that the average of the responses regarding the Performance evaluation process is 3.77, which means that the process is implemented in a medium to hight ratio. Following the analysis of table 1 we can see that the process is implemented in a very hight proportion in the field: IT, hight in: energy, health, trade, hotel industry and a medium level for industry.

Table 7. Descriptive Statistics - Performance evaluation

\begin{tabular}{|l|c|c|c|c|}
\hline \multirow{2}{*}{} & $\mathbf{N}$ & \multicolumn{2}{|c|}{ Mean } & Std. Deviation \\
\cline { 2 - 5 } & Statistic & Statistic & Std. Error & Statistic \\
\hline Performance evaluation & 312 & 3.77 & .052 & .922 \\
\hline Valid N (listwise) & 312 & & & \\
\hline
\end{tabular}

Source: Processing data obtained through SPSS program

From the analysis of table no. 8 that the average of responses on the rewarding has the value 3.62, which means that the process is implemented in a medium proportion to the hight. Following the analysis of table 1 we can see that the process is implemented in a high proportion in the field of: IT, industry and hight in: energy, health, trade and hotel industry.

Table 8. Descriptive Statistics - Rewarding

\begin{tabular}{|l|c|c|c|c|}
\hline \multirow{2}{*}{} & $\mathbf{N}$ & \multicolumn{2}{|c|}{ Mean } & Std. Deviation \\
\cline { 2 - 5 } & Statistic & Statistic & Std. Error & Statistic \\
\hline Rewarding & 312 & 3.62 & .053 & .935 \\
\hline Valid N (listwise) & 312 & & & \\
\hline
\end{tabular}

Source: Processing data obtained through SPSS program

Analyzing table no. 9, it turns out that the average of the responses regarding the Tracking the careers of employees process is 3.83 , which means that the process is implemented in a medium to hight ratio. Following the analysis of table 1 we can see that the process is implemented in a very hight proportion in the field of: energy, IT and hight in: industry, health, trade and hotel industry. 
Table 9. Descriptive Statistics - Tracking the careers of employees

\begin{tabular}{|l|c|c|c|c|}
\hline \multirow{2}{*}{} & $\mathbf{N}$ & \multicolumn{2}{|c|}{ Mean } & Std. Deviation \\
\cline { 2 - 5 } & Statistic & Statistic & Std. Error & Statistic \\
\hline $\begin{array}{l}\text { Tracking the careers of } \\
\text { employees }\end{array}$ & 312 & 3.83 & .052 & .926 \\
\hline Valid N (listwise) & 312 & & & \\
\hline
\end{tabular}

Source: Processing data obtained through SPSS program

\section{CONCLUSIONS}

The results show that the general purpose of human resource management is to contribute to achieving the goal of organizations through people. Thus, the human resources within the participating organizations participated in the research study is the only resource that can have the ability to increase its value over time, unlike all other resources that wear out if not physically, then morally.

Following the analysis of the data collected with the author, the special statistical research software S.P.S.S. (Statistical Package for the Social Sciences), it can be stated that human resources management involves the continuous improvement of the activity of all employees in order to achieve organizational goals. In this sense, the managerial actions must consider each employee as a distinct individuality, with specific characteristics. Successful application of human resources management requires the existence of a performance appraisal system, a system for stimulating and rewarding employee results.

We propose, for a continuous improvement of each process to be based on the activities of the human resources department, subject to research, to be based on:

Human Resource planning: establishing production norms, standardization of working time, sizing work teams, analysis of the staff structure, establishing the necessary staff.

Recruitment: establishing the recruitment and selection criteria, elaboration of recruitment and selection plans, creating a database with potential candidates.

Selection: sorting applications and checking references, elaboration of selection tests, conducting selection interviews.

Orientation: establishing methods for integrating new employees in the workplace, effective integration of new employees at work.

Training and development: identifying the training and improvement needs manifested at the level of the organization, preparation of staff training and development plans, evaluating the efficiency of professional training and improvement programs.

Performance evaluation: defining performance standards, choosing the evaluation methods of the employees, development of employee performance evaluation programs.

Rewarding: job evaluation, establishing the salary system, correlation of the remuneration system with the work efficiency obtained by the employees.

Tracking the careers of employees: elaboration of individual career plans, identification of occupational fields (positions) preferred by employees.

In conclusion, human resources management must represent the set of general and specific activities related to ensuring, maintaining and efficient use of human resources within each organization. The normal development of the activities of the organizations that participated in the research study requires the organization of specialized departments set up in the form of services, offices or departments, depending on the profile and volume of activity, the form of organization and size. Among them must be the human resources department, organized according to the company's own reasoning. 


\section{REFERENCES}

Armstrong, M. (2003). Human resources management. Practice manual. Bucureşti: Editura Codecs.

Chivu, I. (2003). Dimensiunea Europeană a Managementului Resurselor Umane. Bucureşti: Editura Luceafărul.

Coy, B. (2002). Introduction to The Human Resources Audit. Alameda: La Piana Associates Inc.

Deaconu, A., Podgoreanu, S. \& Raşcă, L. (2004). Factorul uman şi performanţele organizaţiei. Bucureşti: Editura ASE.

Gavrilă, T. \& Lefter, V. (2004). Managementul general al firmei. Bucureşti: Editura Economică.

Hardingham, A., Brearley, M., Moorhouse, A. \& Venter, B. (2007). Coaching pentru un coach Dezvoltare personală pentru specialişti în dezvoltare personală. Bucureşti: Editura Codecs.

Jansen, J. (2007). Managementul carierei - Ghid practic. Bucureşti: Editura Polirom.

Jigau, M. (2007). Consilierea carierei. Bucureşti: Editura Sigma.

Maxwell, J. (2003). Cele 17 legi ale muncii în echipă. Bucureşti: Editura Amaltea.

Van Ruysseveldt, J. (2003). International Human resource Management. London: Sage Publications.

Wood, G. (2009). Human Resource Management: A Critical Introduction. New York: Taylor \& Francis.

Kearns, P. (2012). HR Strategy. Oxford: Routledge Publisher. 